\title{
OD DZIEJÓW HISTORIOGRAFII DO DZIEJOWOŚCI TEKSTÓW HISTORIOGRAFICZNYCH
}

\author{
Violetta JULKOWSKA
}

\section{ABSTRACT}

\section{From history of historiography to historicity of historiographical texts}

The article attempts to define the history of historiography as a subdiscipline of history; it indicates the numerous competences of historians of historiography which are nessesary for undertaking an (auto)reflection around the history of their discipline, for touching the theoretical and methodological aspects of historiography, and for the study of historicity of historiographical texts. The author asks about the current status of the history of historiography and new horizons of research. Regarding the field of changes in the ways of comunication, she sees potential chances for increasing the interest of new recipients in the history of historiography. The author amplifies the weft of reception, understood as a phenomenon that belongs to the comunication situation occuring between the author of transmission and his recipients. The author refers to the inspiration of the methodological conception of the school of reception aesthetics from Constance (W. Iser, R. Jauss) and the hermeneutics of H-G. Gadamer. Reception is a new concept for presenting the history of historiography as a field of research on the historicity of historical works.

\section{KEYWORDS:}

history of historiography, reception, reception aesthetics, horizon of expectations, historical culture 


\section{HISTORIA HISTORIOGRAFII JAKO OBSZAR PRAK- TYKOWANIA KOMPETENC]I INTERPRETACY]NYCH 1 KOMUNIKACY]NบCH}

Historia historiografii na przestrzeni ostatnich kilkudziesięciu lat swojego naukowego bytu wypracowała różne metody prowadzenia dyskursu wokół dorobku historii, jako dyscypliny głównej, której była i jest częścią. Współczesna historia historiografii stara się, by nie postrzegano ją jako wyłącznie chronologiczny zapis dziejów dyscypliny, a raczej jako rodzaj złożonej (auto)refleksji o historii, historykach i historiografii, dodajmy, że refleksji o charakterze krytycznym, uprawianej przez historyków historiografii oraz sporadycznie przez historyków, z pozycji różnych ujęć badawczych. Historycy historiografii koncentrują swoją refleksję nie tylko na dziełach i osobach, lecz także na wielkich ideach historii, problemach historiograficznych, również na pograniczach metodologii i socjologii, a swoją dziedzinę badań widzą w kontekście wydarzeń historycznych, rozwoju nauki i przemian w kulturze. Jedną z istotnych cech tego namysłu nad własną dyscypliną (historią) jest dostrzeganie i rejestrowanie zmieniających się perspektyw i kontekstów badawczych, w jakich dokonuje się pisanie historii, a także ich wpływu na rozwój dyscypliny. Można więc postawić tezę, że historia historiografii poprzez swoje badania nadal wypracowuje i wzbogaca własną tożsamość jako subdyscyplina, swoim spektrum obejmując z jednej strony dzieje historiografii, ale też z drugiej tworząc rodzaj reprezentacji przemian dokonujących się w dyscyplinie głównej. Badanie dziejowości tekstów historiograficznych to jedna $\mathrm{z}$ metod uchwycenia horyzontów wspomnianych przemian.

Zakres zainteresowań badawczych historii historiografii ujawnia wielość niezbędnych kompetencji badawczych jakie powinny cechować historyka historiografii. Tenże z racji swoich zainteresowań poruszając się w wielowiekowym, a na dodatek palimpsestowym świecie tekstów kultury, musi posiadać świadomość spotykania twórców $i d z i e t$ reprezentujących odmienne niż on sam horyzonty poznawcze, ideowe, religijne, estetyczne. Co więcej, w szerzej zakrojonych badaniach historycznohistoriograficznych ujawniają się i zderzają różne poglądy na dzieje, co związane jest z koniecznością ich rozpoznawania i definiowania, często dekonstruowania. Historycy historiografii mierzą się z rzadko ujawnianymi wprost postawami teoriopoznawczymi autorów prac, $\mathrm{z}$ odmiennie pojmowanymi przez nich zakresami semantycznymi stosowanych pojęć, czy wreszcie z polem działania określonych konwencji kulturowych i artystycznych. Różnice w schematach poznawczych i interpretacyjnych stawiają historyka historiografii wobec kolejnych wyzwań, a sposób ich podjęcia lub ignorowania wpływa znacząco na stopień osiągnięć badawczych. 
Zatem sposób w jaki przebiega praca analityczno-interpretacyjna historyka historiografii nad dawnym i współczesnym dorobkiem historiograficznym jest uwarunkowany z jednej strony przez moment rozwoju nauki historycznej, obowiązujące trendy badawcze i mody historyczne, a z drugiej przez stopień indywidualnej świadomości i wrażliwości metodologicznej badającego oraz znajomosśc szerokich kontekstów historycznych i kulturowych. W oparciu o te zmienne historyk historiografii kształtuje swoją refleksję wokół prac historiograficznych, wpływając na kształtowanie się opinii na ich temat.

\section{KRĄG PYTAŃ NIERETORYCZNYCH WOKÓ $t$ OBECNEGO STATUSU SUBDYSCYPLINY}

Historia historiografii jako rodzaj metarefleksji formułowanej wobec dziedziny tak rozległej jaka jest historia, obarczonej długą tradycją, a mimo to uchodzącej w powszechnej opinii za wiedzę przystępną, pełni różne funkcje. Jedne z pierwszych, wyznaczone już w początkowym okresie profesjonalizacji historii, polegały na swoistym archiwizowaniu tekstów poprzez włączanie ich do bibliografii oraz na krytycznym omawianiu różnych dziedzin naukowego piśmiennictwa historycznego, a z czasem na analitycznym opracowywaniu całości dorobku poszczególnych historyków i środowisk historycznych w sposób systematyzujący i/lub syntetyzujący. Wraz z rozwojem dyscypliny głównej do wspomnianych zadań historyków historiografii doszły nowe funkcje, polegające na tworzeniu tekstów orientujących w złożoności zagadnień historycznych. W zależności od środowiska historiograficznego i preferowanych trendów badawczych - prace historyków historiografii przybliżają dzieje idei historycznych, problemy metodologiczne i teoriopoznawcze, $w$ tym związane z tworzeniem się i działaniem środowisk historycznych, badaniem narracji historycznej lub konstrukcją biografii naukowych nowego typu oraz współczesną krytyką naukowa uprawianą w polu historiografii'.

Pojawia się zatem pytanie nieretoryczne, wobec którego nasza subdyscyplina stawiana jest od początku swego istnienia. Pytanie o to, w jakim stopniu i dla jakiego kręgu odbiorców praca historyka historiografii jest tekstem ważnym, interesującym poznawczo, opiniotwórczym?

W odpowiedzi można wskazać wąskie grono fachowców, gdyż trwający od dziesięcioleci proces profesjonalizacji historii i specjalizacji tekstów skutkował

1 Na liście kluczowych dla przedmiotu historia historiografii prac nie powinno zabraknąć ujęć historyków reprezentujących dawne i współczesne polskie środowiska historii historiografii. Wariantowy i autonomiczny wybór powinien podkreślać odmienność dróg i specyfikę prowadzonych badań. 
stopnieniem początkowo licznego grona czytelników². Współcześnie dwie tendencje mają wpływ na zainteresowane publikacjami historyków historiografii, z jednej strony mała dostępność niszowych wydawnictw naukowych, sprawia że tradycyjny sposób przekazu ulega stałemu ograniczaniu, z drugiej dygitalizacja dorobku i cyfryzacja współczesnego obiegu potencjalnie otwierają naszą dyscyplinę na nowych odbiorców. Dlatego kolejne pytanie dotyczy sytuacji budowania przekazu i komunikacji w świecie zmienionym przez obecność zaawansowanych technologii i społecznych mediów komunikacyjnych. Jaka jest szansa zaistnienia w nim dziedzin wyspecjalizowanych takich jak historia historiografii? Prawdopodobnie nie większa niż przed erą nowych technologii, z racji specyfiki tekstów specjalistycznych, kierowanych do określonych czytelników. Najbliższy krąg odbiorców historii historiografii stanowili i nadal stanowią historycy i metodolodzy historii, a także zobligowani w różnym stopniu programem kształcenia - studiujący adepci historii, od licencjatów po doktorantów. Dalsze kręgi tworzą sporadycznie przedstawiciele innych dziedzin historycznych, $\mathrm{w}$ tym historii sztuki oraz antropologii historii, jak również dziedzin pokrewnych humanistycznie, do których należą historia i teoria literatury oraz filozofia, czy też powinowatych przez nauki społeczne takich jak kulturoznawstwo, socjologia czy nauki polityczne.

Powyższa konstatacja nie unieważnia i nie zmienia zasadniczego celu historii historiografii, natomiast może uświadomić potrzebę istotnej zmiany w zakresie formy komunikowania się z konkretnymi kręgami stałych i potencjalnych odbiorców. To oznacza konieczność opanowania przez środowisko historyków nowych kompetencji, o ile uznana zostanie za ważną potrzeba większego upublicznienia problemów, którymi się nasza subdyscyplina zajmuje. Historia historiografii nie jest bowiem w swoich treściach bardziej hermetyczna od innych autorefleksyjnych ujęć, przeciwnie, jej teksty potrafią znakomicie budować podstawy wspótczesnej kultury historycznej, rozumianej jako badanie sposobów obecności przesztości w teraźniejszości $i^{3}$.

Problem rozszerzenia możliwych pól recepcji współczesnej historii historiografii tkwi raczej w trafnym wyborze strategii komunikowania, która byłaby nastawiona na przewidywanego odbiorcę, nie zaś w rezygnacji z naukowości badań. W ramach tej strategii istotne staje się rozumienie transferu wiedzy pomiędzy różnymi obszarami komunikacji, które posługują się specyficznymi dla siebie kodami językowymi, a przy tym odwołują się do innych kontekstów kulturowych. Zadanie złożone, ale mające już przykłady owocnych rozwiązań choćby w postaci interdyscyplinarnych platform

2 Por. O zjawiskach recepcji tekstów historiograficznych i mechanizmach partycypacji różnych kręgów odbiorców w: V. Julkowska, Historia dla wyobraźni. Recepcja i interpretacja piśmiennictwa historycznego Karola Szajnochy, Poznań 2010, s. 170-178.

3 P.O. Loew, Gdańsk i jego przeszłość. Kultura historyczna miasta od końca XVIII wieku do dzisiaj, przeł. J. Mosakowski, Gdańsk 2003, s. 11-14. 
czasopism cyfrowych, które zaczynają tworzyć szerszą niż tradycyjne media przestrzeń komunikowania. Innym problemem, którym od pewnego czasu interesują się historycy jest wizualizacja wiedzy o przeszłości w procesie komunikacji. Przekracza on granice subdyscyplin i zmienia sposób myślenia o przekazie i upowszechnianiu wiedzy na temat przeszłości. Nietrywialnie, krytyczne rozumienie problemu wizualizacji przekazu w połączeniu z dodatkowymi aspektami jakie wynikają z jego multimediatyzacji, a więc konieczności zróżnicowania sposobu przedstawiania, hipertekstowości (symultaniczne i wieloaspektowe analizy informacji) oraz interakcyjności procesu komunikacji dzięki nowym technologiom komunikacyjnym, zasadniczo zmienia tradycyjną sytuację transferu wiedzy, ale paradoksalnie zwiększa możliwości oddziaływania i upowszechniania tekstów specjalistycznych.

\section{NOWE HORYZONTY BADAŃ HISTORIOGRAFICZNYCH}

Problem tytułowy, czyli badanie dziejowości tekstów i praktyk historiograficznych, otwiera nowe horyzonty badań, rozszerzając je o inspiracje z obszaru refleksji filozoficznej, badań literaturoznawczych i kulturoznawczych. Dziejowość tekstów historiograficznych jest problemem złożonym, a przywołanie kategorii palimpsestu, pozwala lepiej zrozumieć, że trwanie w kulturze symbolicznych zasobów (w tym historiograficznych) odbywa się za sprawą kolejnych interpretacji/reinterpretacji, nawet wówczas gdy są one przesłonięte historycznym nawarstwianiem się sensów i czasowo nieobecne. Zjawisko nakładania się różnych warstw kulturowych w akcie tworzenia jednostkowych obrazów przeszłości przez różnych historyków występuje, gdy kolejne pokolenia recypują wcześniejsze doświadczenia. Palimpsestowość historiografii ujawnia się również, gdy jednocześnie weźmiemy pod uwagę ponadindywidualny proces przemiany pewnych zastanych wzorców w inne. Współczesne praktyki pisarskie historiografii kształtowały się jeszcze w XIX stuleciu na pograniczu literatury i historii, $\mathrm{w}$ toku wielokrotnej wymiany i dookreślania reguł, niejednokrotnie $\mathrm{w}$ wyniku trwających latami dyskusji lub eksperymentowania $\mathrm{z}$ formą wypowiedzi ${ }^{4}$. Wspólnym obszarem dyskusji dla literatury i historii okazała się „narracja” jako strategia opowiadania o zdarzeniach oraz „(o)powieść” jako pojemna forma gatunkowa. W kontekście kształtujących się dynamicznie do połowy XIX wieku odmian prozy realistycznej, historiografia zaliczana była początkowo do wspólnego obszaru

4 V. Julkowska, Historiograficzny palimpsest. Problem przedstawiania przeszłości w polskiej historiografii doby romantyzmu, w: Romantyzm w lustrze postmodernizmu (i odwrotnie), red. W. Hamerski, M. Kuziak, S. Rzepczyński, Warszawa 2014, s.119-120. 
piśmiennictwa. Wraz z powstaniem seminariów historycznych i postępującą specjalizacją badań historycznych historia zaczęła wyróżniać się specyficznymi regułami postępowania badawczego, stosowanymi przez profesjonalnych historyków. O ile doba romantyczna była czasem pojawiania się wariantowo różnych prób pisarstwa historycznego, zależnie od roli i zadań przypisywanych historii, to kształtowanie się profesjonalnych środowisk historycznych pod koniec XIX wieku (uniwersytety, archiwa) doprowadziło do powstania odrębnego dyskursu historycznego i potrzeby krytycznej refleksji na wzór ośrodków europejskich.

Studium recepcji poglądów teoretycznych Lelewela przybliża problem dziejowości historii historiografii, ponieważ jego rozważania o znaczeniu historii historiografii w ramach wyspecjalizowanej refleksji nad historią jako dziedziną badawczą pojawiły w momencie narodzin historyzmu, jeszcze przed fazą profesjonalizacji historii na gruncie polskim i przed budowaniem jej podstaw instytucjonalnych. Lelewel był autorem pierwszego, całościowego wykładu historii historiografii na gruncie akademickim, czyniąc zeń obowiązkowy wstęp do badań historycznych, poprzedzający kursowy wykład historii powszechnej ${ }^{5}$. Podobnie jak przedstawiciele niemieckiej szkoły historycznej z Getyngi uważał gruntowną i krytyczną znajomość dawnego piśmiennictwa historycznego za istotny składnik warsztatu pisarskiego historyka i jego kultury historycznej, o braku której pisał Ksawery Liske jeszcze w końcu lat 60. XIX stulecia ${ }^{6}$. Refleksja Lelewela nie ograniczała się do wykładu historii historiografii rozumianej jako kanon dzieł wybitnych historyków starożytnych, ani też do prezentacji przykładów kunsztu narracyjnego, co praktykowano już od wieków w obszarze retoryki. Lelewel w ramach zakreślonych przez jego historykę postawił historii historiografii zadanie trudniejsze. W jego projekcie miała ona stać się obszarem refleksji krytycznej nad historią rozwoju historiografii i porównawczego badania tekstów pochodzących z różnych epok historycznych. Analizował gatunki piśmiennictwa historycznego i odnotowywał wypowiedzi historyków, wskazując na szeroki kontekst kulturowy z jakiego one wyrastały. Badał również zmiany zachodzące na przestrzeni wieków w sposobie reprezentowania przeszłości, odnosząc je ostatecznie do współczesnych jego czasom standardów. Lelewel jako pierwszy zaakcentował rozróżnienie między dyskursem historycznym opowiadającym a sprawozdającym. Wkład metodologiczny Lelewela nie był przez współczesnych doceniony, choć jego wizja historii stała się na dziesiątki lat punktem orientującym w antynomicznie budowanej dyskusji wokół

5 A. Wierzbicki, Historiografia polska doby Romantyzmu, Wrocław 1999, s. 70-73. V. Julkowska, Retoryka w narracji historycznej Joachima Lelewela, Poznań 1998, s. 23-26.

6 K. Liske, Übersicht der polnischen historiscen Literatur der lezten Jahre, „Historische Zeitschrift”, t.XVII, 1867 , s.359-410. 
koncepcji dziejów Polski (szkoła lelewelowska kontra szkoła naruszewiczowska) ${ }^{7}$. Dopiero dwudziestowieczne studia historiograficzne M. J. Serejskiego ${ }^{8}$ zwrócily uwagę na niewyzyskane wcześniej idee i koncepcje w obszarze historii historiografii, z kolei badania nad potencjałem teoretycznym Lelewela, prowadzone przez N. Assorodobraj-Kulę ${ }^{9}$, a następnie J. Topolskiego ${ }^{10}$ i A.F. Grabskiego", odkrywały metodologiczne aspekty badań historiograficznych. Dla późniejszych badaczy dzieje historiografii ponownie stały się obszarem, pozwalającym na obserwację relacji pomiędzy dyskursem a narracją, dzięki dyskusji podjętej przez strukturalistów, a kontynuowanej po zwrocie narratywistycznym.

Problem badań nad dziejowością tekstów historycznych jest na gruncie historii historiografii konceptem dopiero rozwijanym, z pomocą metod interpretacji tekstów inspirowanych przez hermeneutykę i estetykę recepcji. Zmieniające się historycznie style recepcji, badane w kontekście kulturowym epoki i rozwoju historiografii, wskazują na źródła fenomenu popularności określonych gatunków historiografii i form narracji, ale również prowadzą do rozpoznania mechanizmów nawarstwiania się sensów kulturowych. Uchwycenie zmian recepcji tekstów przez historycznie uwarunkowanych odbiorców krytycznych, doprowadziło w wyniku badań do konstatacji na temat istnienia dialogu między dziełami a ich czytelnikami, zachodzącego w historycznie zmieniającym się polu historiografii ${ }^{12}$.

Badanie dziejowości tekstów to propozycja potraktowania historii historiografii, nie jako konwencjonalnego zabiegu inwentaryzacyjnego, lecz jako złożonej refleksji o charakterze kulturowym, w pełni podkreślającej historyczność historiografii. $\mathrm{W}$ procesie historycznym kolejnych recepcji dzieła historycznego, wraz z powtórnym przyswojeniem tego dzieła przez nowe pokolenia czytelników, dokonuje się nieustannie mediacja między dziejopisarstwem przeszłości i teraźniejszości oraz między ugruntowaną przez tradycję wartością tego pisarstwa a jego aktualizacją przez współczesnych odbiorców, według odmiennych konwencji czytania i w zmienionym kontekście kulturowym ${ }^{13}$. W konsekwencji jedną z kluczowych kategorii recepcji,

7 W. Smoleński, Szkoty historyczne w Polsce. Gtówne kierunki poglądów na przeszłość [1886], przed. A.F. Grabski, Warszawa 1986.

8 M.J. Serejski, Koncepcja historii powszechnej Joachima Lelewela, Warszawa 1958.

9 N. Assorodobraj, Ksztaltowanie się zatożeń teoretycznych historiografii Joachima Lelewela, w: Z dziejów polskiej myśli filozoficznej i spotecznej, t. III, Warszawa 1957.

10 J. Topolski, Lelewel a postęp metodologiczny historiografii europejskiej. Refleksje o „Historykach” Joachima Lelewela, w: Joachim Lelewel człowiek i dzieto, red. K. Bartkiewicz, Zielona Góra 1888, s. 28-35.

11 A.F. Grabski, Joachima Lelewela koncepcja dziejów Polski, w: Perspektywy przeszłości. Studia i szkice historiograficzne, Lublin 1983, s.134-220.

12 Por. V. Julkowska, Historia dla wyobraźni. Recepcja i interpretacja pisarstwa historycznego Karola Szajnochy, Poznań 2010, s. 170-178.

13 Por. R. Jauss, Historia literatury jako prowokacja dla nauki o literaturze, w: tegoż, Historia literatury jako prowokacja, przełożyła M. Łukasiewicz, posłowie K. Bartoszyński, Warszawa 1999, s. 126-138; 
uwzględniającą dziejowość tekstów i ich recepcji, jest przyjęty za R. Jaussem horyzont oczekiwań odbiorcy, bliski Gadamerowskiej koncepcji fuzji horyzontów, rozumianej jako zbiór przeświadczeń czytelnika, umożliwiający mu odbiór dzieła w zmieniającym się kontekście kulturowym. Zbiór ten, w przypadku każdego dzieła pojawiającego się $\mathrm{w}$ danym historycznie momencie, określony jest przez uprzednie rozumienie gatunku, przez formę i tematykę uprzednio znanych dzieł, a także opozycję języka poetyckiego i praktycznego.

Im bogatsze jest wyposażenie horyzontu oczekiwań, a tak dzieje się w przypadku odbiorcy krytycznego, tym łatwiejszy staje się odbiór dzieł nowatorskich, wykraczających poza standardowy dla danego kręgu i w danym momencie historycznym horyzont oczekiwań. Konkludując można przyjąć, że staranny proces edukacji akademickiej, w oparciu o bogatą reprezentację tekstów z obszaru historii historiografii, powinien prowadzić do przygotowania czytelnika krytycznego i do poszerzenia jego horyzontu oczekiwań. Za Gadamerem można powtórzyć, że uzyskanie określonego horyzontu oznacza, że uczymy się sięgać wzrokiem ponad bliskość, nie po to, by od niej abstrahować, lecz by lepiej widzieć na tle pewnej większej całości i we właściwych proporcjach $^{14}$. Rozumienie tradycji wymaga uprzedniego rozszerzenia historycznego horyzontu recepcji, co odpowiada konieczności rozszerzenia pola widzenia, niezbędnego do interpretacji rozumiejącej. Kształtująca się w toku podjętego wysiłku intelektualnego historyczna świadomość wychodzi wówczas naprzeciw świadectwom przeszłości. ${ }^{15}$ Badanie recepcji uczy dystansu wobec mierzenia przeszłości miarą własnych oczekiwań sensu, poddaje próbie horyzont współczesności, ale zarazem tworzy szansę na rozumienie historycznych sensów odmiennych, co ma miejsce w procesie stapiania się horyzontów. ${ }^{16}$

Moim osobistym doświadczeniem historyka historiografii w spotkaniach z tradycją historiograficzną XIX wieku było wielokrotne odczucie odmienności sensu nadawanego przeszłości przez ówczesnych autorów. Gadamer uczy, aby powstającego wówczas napięcia pomiędzy dawną tradycja a współczesnością nie zakrywać przez naiwną niwelację lecz rozwijać ${ }^{17}$. Zadanie historyka historiografii w myśl tej rady widzę jako świadomą pracę nad zrozumieniem dawnego i nowego sensu, który rodzi się z dostrzegania różnicy dzięki nowej perspektywie widzenia.

14 H-G. Gadamer, Prawda i metoda. Zarys hermeneutyki filozoficznej, przeł. i wstępem opatrzył B. Baran, Warszawa 2004, s. 417 i n.

15 Por. B. Kürbis, Historia wpisana w teraźniejszość. O Kronice polskiej mistrza Wincentego zwanego Kadtubkiem, [w: ] Studia nad świadomością historyczna Polaków, pod redakcją J. Topolskiego, Poznań 1994, s. 35-36.

16 H-G. Gadamer, Prawda i metoda, s. 419.

17 Tamże, s. 420. 